Creative Commons User License: CC BY-NC-ND

Abstracted by: EBSCOhost, Electronic Journals Service (EJS), Google Scholar, Journal Seek, Scientific Commons,

Food and Agricultural Organization (FAO), CABI and Scopus
Journal of Agricultural Extension

Vol. 23 (2) April, 2019

ISSN(e): 24086851; ISSN(Print); 1119944X

http://journal.aesonnigeria.org

http://www.ajol.info/index.php/jae

Email: editorinchief@aesonnigeria.org

\title{
Beneficiaries' Perception of the West Africa Agricultural Productivity Programme Implemented by the University of Nigeria Nsukka in Enugu State, Nigeria
}

https://dx.doi.org/10.4314/jae.v23i2.4

\section{Adeogun, Taiwo $\mathrm{F}$}

Department of Agricultural Extension university of Nigeria Nsukka

Email: adeogun.taiwo@unn.edu.ng Phone: +234-8037717797

\section{Agwu. Ekwe A}

Department of Agricultural Extension university of Nigeria Nsukka

Email: ekwe.agwu@unn.edu.ng Phone: +234-8034024251

\section{Abstract:}

This study assessed beneficiaries' perception of the University of Nigeria, Nsukka West Africa Agricultural Productivity Programme activities in Enugu State. The study sought to ascertain participants' perception on the effectiveness of programme, as well as identified participants' level of satisfaction with its implementation and also determined possible constraints to its implementation. Multi stage sampling procedure was used to sample $80 \%$ of the participants of the programme i.e. 87 persons. Data were collected using interview schedule and analysed using mean statistics. Participants perceived that the type of personnel used for the programme operations $(\bar{x}=2.55)$, the farmers' sensitization process in preparation for the programme $(\bar{x}=2.25)$ and use of mobile phone in disseminating information on the programme activities $(\bar{x}=2.18)$ were effective in the programme implementation. Participants were satisfied with the method of information dissemination on the WAAPP activities $(\bar{x}=2.22)$ as well as the farmers sensitization processes on the programme activities $(\bar{x}=2.12)$. The major constraints militating against effective implementation /utilization of WAAPP programme were insufficient credit facilities $(\bar{x}=2.62)$ and inadequate funding attached to each package of the project $(\bar{x}=2.59)$. The study recommends that government should increase farmers' involvement in the planning and implementation of future projects as this will go a long way in making them better.

Key word: West Africa Agricultural Productivity Programme (WAAPP), programme effectiveness and beneficiaries' satisfaction

\section{Introduction}

Agriculture plays a major role in the economies of West African countries, contributing more than 20 percent to its GDP and providing income and employment to about 70 percent of the region's population and about 20 percent of the total merchandise exports (Bernard \& Frankwell, 2014). Therefore, the performance of the sector is important to the economic growth and development of the majority of the Economic Community of West African States countries (ECOWAS). In order to significantly reduce poverty in the region, it becomes imperative to increase investment in agriculture which of course is a renewable and sustainable investment. Based on this background, the Comprehensive African Agricultural Development Programmes (CAADP) 2001 framework projected the need for agriculture growth to attain at least a 6 percent rate. Attaining this growth 
Creative Commons User License: CC BY-NC-ND

Abstracted by: EBSCOhost, Electronic Journals Service (EJS), Google Scholar, Journal Seek, Scientific Commons,

Food and Agricultural Organization (FAO), CABI and Scopus
Journal of Agricultural Extension

Vol. 23 (2) April, 2019

ISSN(e): 24086851; ISSN(Print); 1119944X

http://journal.aesonnigeria.org

http://www.ajol.info/index.php/jae

Email: editorinchief@aesonnigeria.org

http://eoi.citefactor.org/10.11226/v23i2

requires substantial increase in agricultural productivity in terms of yield and output of which WAAPP is anchored on.

The WAAPP project which emphasis and encourages productivity in agriculture has been implemented in Nigeria using mainly the universities as channel for the project implementation. The University of Nigeria, Nsukka (UNN) is one of the thirteen (13) universities in Nigeria that participated in implementing the project. Since inception in 2013, catfish production, distribution of maize seeds, and improved cassava stem distribution have been the major focus of WAAPP dissemination unit of the University of Nigeria, it is expected that farmers will benefit from improved crop varieties and aquaculture, while agribusinesses/marketers will benefit from advanced innovations in agricultural product handling and processing technologies.

For these technologies to elicit expected responses from the target beneficiaries, their perception of the efforts being made becomes important. Perception is the process of attaining awareness or understanding of sensory information from seeing, hearing, smelling, touching and orienting (Chambers Dictionary, 2014). Perception is our recognition and interpretation of sensory information, it also includes how we respond to information (Yolanda, 2013). In other words, a person is confronted with a situation or stimuli. The person interprets the stimuli into something meaningful based on prior experiences. However, what an individual interprets or perceives may be substantially different from reality. Perception provides information about the environment around us, and such information emerges from the counterfactual dependence between the environment and the corresponding perceptual experiences (Otávio, 2013).

The Federal Government of Nigeria saw the need to evolve new agricultural programmes for the rescue of mono-cultural economy, such programmes include operation feed the nation, agricultural transformation agenda and West Africa Agriculture Productivity programme (WAAPP) etc). These programmes were fashioned to revolutionize agricultural sector of Nigerian economy which was derailing from its normal contribution to the economy.

Unfortunately, many of these agricultural programmes did not yield anticipated positive results because farmers were not involved in the design of such programmes and in most cases top bottom approaches were used, hence, farmers felt needs were not addressed. Farmers were considered as conservative; they tend to resist changes especially when the change seems not to meet their felt needs. These led to many farmers losing their confidence in agricultural development policies or programmes for the fact that the above reasons are not considered

Given this peculiar nature and approach of WAAPP as well as the fact that the UNN arm of WAAPP is a university based one, it then became important to examine how the programme has been implemented around the University of Nigeria catchment area and the general perception of farmers towards the implementation process of the programme.

\section{Purpose of the study}

The overall purpose of the study was to ascertain the beneficiaries' perceptions of the University of Nigeria West Africa Agriculture Productivity Programme (WAAPP) in Enugu state. Specifically, the study sought to:

- ascertain participants' perception of the effectiveness of the programme,

- identify participants' level of satisfaction in the implementation of the programme; and

- determine perceived constraints to participation. 
Creative Commons User License: CC BY-NC-ND

Abstracted by: EBSCOhost, Electronic Journals Service (EJS),

Google Scholar, Journal Seek, Scientific Commons,

Food and Agricultural Organization (FAO), CABI and Scopus
Journal of Agricultural Extension

Vol. 23 (2) April, 2019

ISSN(e): 24086851; ISSN(Print); 1119944X

http://journal.aesonnigeria.org

http://www.ajol.info/index.php/jae

Email: editorinchief@aesonnigeria.org

\section{Methodology}

http://eoi.citefactor.org/10.11226/v23i2

The study was carried out in Enugu State, Nigeria. Two Local Government Areas (LGAs) namely Nsukka and Udenu LGAs were purposively selected due to proximity of the university and because of the execution of the project in the areas. In the second stage, four town communities (Obukpa, Imilike, Okpuje, and Obimo) where UNN-WAAPP farmers predominate were purposively selected. In the third stage, $80 \%$ of the participants from each town community were selected.

The samples were drawn as follows:

Table 1: Population and sample

\begin{tabular}{cccc}
\hline LGA & Town Community & $\begin{array}{c}\text { Number } \\
\text { Participants }\end{array}$ & $\begin{array}{c}\mathbf{8 0 \%} \text { of } \\
\text { Participants }\end{array}$ \\
\hline Nsukka & Obukpa & 26 & 21 \\
& Okpuje & 25 & 20 \\
\multirow{2}{*}{ Udenu } & Obimo & 32 & 26 \\
& Imilike Enu & 25 & 20 \\
& Total & $\mathbf{1 0 8}$ & $\mathbf{8 7}$ \\
\hline
\end{tabular}

Thus, the total sample size for the study was 87 respondents. However, 51 copies of the interview schedule representing $59 \%$ of the distributed instrument were correctly answered and used for analysis

To ascertain the perception of the effectiveness of the programme at various level of implantation, a three point Likert-type scale of Very effective $=3$, effective $=2$ and not effective $=1$ was used. The values were added to obtain a total of 6 which was later divided by 3 to get a bench mark mean of 2. Values with mean score of 2 and above was regarded as effective while values less than the bench mark mean of 2 were regarded as not effective. the same goes with participant level of satisfaction a three point Likert-type scale of Very satisfactory $=3$, satisfactory $=2$ and not satisfactory $=1$ was used The values were added to obtain a total of 6 which was later divided by 3 to get a bench mark mean of 2 . Values with mean score of 2 and above was regarded as satisfactory while values less than the bench mark mean of 2 were regarded as not satisfactory. The perceived constraints were measured using a three point Likert-type scale of Very serious = 3 , serious $=2$ and not serious $=1$ was used. The values were added to obtain a total of 6 which was later divided by 3 to get a bench mark mean of 2 . Values with mean score of 2 and above was regarded as major constraints while values less than the bench mark mean of 2 were regarded as a minor constraint. Data were analysed using means, frequency, percentage and standard deviation.

\section{Results and Discussion}

\section{Participants' Perception of WAAPP effectiveness}

Entries in Table 2 show that programme variables considered effective include: type of personnel used for the programme operations $(\bar{x}=2.55)$, the farmers' sensitization process in preparation for the programme $(\bar{x}=2.25)$, use of mobile phone in disseminating information on the programme activities $(\bar{x}=2.18)$, the process of registration for the programme $(\bar{x}=2.14)$, timely input provision by the programme $(\bar{x}=2.12)$, the channel used for inputs redemption $(\bar{x}=2.02)$ and the seed distribution process by the programme $(\bar{x}=2.02)$. Such perception of the projects' activities by 
Creative Commons User License: CC BY-NC-ND

Abstracted by: EBSCOhost, Electronic Journals Service (EJS), Google Scholar, Journal Seek, Scientific Commons,

Food and Agricultural Organization (FAO), CABI and Scopus
Journal of Agricultural Extension

Vol. 23 (2) April, 2019

ISSN(e): 24086851; ISSN(Print); 1119944X

http://journal.aesonnigeria.org

http://www.ajol.info/index.php/jae

Email: editorinchief@aesonnigeria.org

http://eoi.citefactor.org/10.11226/v23i2

respondents could be as a result of their participation in the project activities coupled with the knowledge gathered from such participation. However, the respondents perceived the following as not being effective: the crops/seeds supplied to the farmers by the programme $(\bar{x}=1.92)$, the timely fertilizer provision and its regularity $(\bar{x}=1.73)$ and fertilizer distribution process by the programme $(\bar{x}=1.51)$. These areas that were not considered as effective could hinder the general success of the project if not improved upon. Table 2 showed a grand mean of $(\bar{x}=2.04)$, the implication is that putting all the variables together, the participants perceived the WAAPP effectiveness very highly.

With this result one can infer that the programme met the participants' needs. It is expected that the high perception of WAAPP effectiveness will attract more farmers to participate and adopt the farming technologies and improve their knowledge for increase agricultural productivity. This result corroborates with the findings of Emmanuel, (2015), and Nwokocha , Anyaegbunam, \& Igwe, (2018) who also observed a high level of participant perception on the effectiveness of WAAPP project.

Table 2: Participants' perception of WAAPP effectiveness

\begin{tabular}{lcc}
\hline Farmers' perception on WAAPP programme & Mean & Standard deviation \\
\hline The process of registration for the programme & $\mathbf{2 . 1 4}$ & 0.693 \\
The channel used for inputs redemption & $\mathbf{2 . 0 2}$ & 0.836 \\
Timely input provision by the programme & $\mathbf{2 . 1 2}$ & 0.864 \\
Fertilizer distribution process by the programme & 1.51 & 0.857 \\
The seed distribution process by the programme & $\mathbf{2 . 0 2}$ & 0.795 \\
$\begin{array}{l}\text { Use of mobile phone in disseminating information } \\
\text { on the programme activities }\end{array}$ & $\mathbf{2 . 1 8}$ & 0.767 \\
$\begin{array}{l}\text { The farmers sensitization process in preparation } \\
\text { for the programme }\end{array}$ & $\mathbf{2 . 2 5}$ & 0.659 \\
$\begin{array}{l}\text { The type of personnel used for the programme } \\
\text { operations }\end{array}$ & $\mathbf{2 . 5 5}$ & 0.577 \\
$\begin{array}{l}\text { The timely fertilizer provision and its regularity } \\
\text { The crops/seeds supplied to the farmers by the } \\
\text { programme }\end{array}$ & 1.73 & 0.802 \\
Total & 1.92 & 0.759 \\
Grand mean & $\mathbf{2 0 . 4 4}$ & \\
\hline
\end{tabular}

Source: Field Survey, 2017

\section{Level of Participants' Satisfaction with WAAPP Programme}

Information in Table 3 reveals the respondent's level of satisfaction with the project implementation process. Participants were satisfied with the following method of information dissemination on the WAAPP activities ( $\bar{x} 2.22)$, the quality of maize seed provided $(\bar{x}=2.15)$, the farmers sensitization processes on the programme activities $(\bar{x}=2.12)$, the channels used in execution of the scheme $(\bar{x}=2.2)$ and the general operations of the programme $(\bar{x}=2.08)$. Participants' satisfaction on these implementation processes of the project is that the aim of the project was to improve farm yield and productivity. 
Creative Commons User License: CC BY-NC-ND

Abstracted by: EBSCOhost, Electronic Journals Service (EJS), Google Scholar, Journal Seek, Scientific Commons,

Food and Agricultural Organization (FAO), CABI and Scopus
Journal of Agricultural Extension

Vol. 23 (2) April, 2019

ISSN(e): 24086851; ISSN(Print); 1119944X

http://journal.aesonnigeria.org

http://www.ajol.info/index.php/jae

Email: editorinchief@aesonnigeria.org

However, the participants were not satisfied with the following: availability of feed provided for the cat fish production $(\bar{x}=1.94)$, the ability to reconcile with the list of the farmers $(\bar{x}=1.96)$, timely provision of the inputs $(\bar{x}=1.88)$, the maize seed distribution method $(\bar{x}=1.82)$, availability of water supply $(\bar{x}=1.69)$, the quantity of maize seed/cassava $(\bar{x}=1.60)$, the cassava stem distribution method $(\bar{x}=1.52)$ and the level of subsidy provided by the programme $(\bar{x}=1.52)$. These areas of unsatisfactory implementation process are also critical especially lack of water supply for the cat fish production and the level of subsidy provided by the programme. This can hinder the success of the project. Ensuring that these inputs are provided as at when needed will be of importance and other lapses noticed during the implementation stages be adequately improved upon if the set goals of the project must be achieved. From the result participants were satisfied with the method of information dissemination on the WAAPP activities, the farmers sensitization processes on the programme activities, the channels used in execution of the scheme. This might be because of the communication method used during the programme. The use of different methods of communication in extension information delivery maximizes program efficiency, effectiveness and client satisfaction (Anugwa, Agwu, Anyanwu, 2017). The grand mean of $(\bar{x}=1.89)$ which is a little below the bench mark mean of $(\bar{x}=2.0)$ showed that when all variables are put together, there is a low level of satisfaction of WAAPP programme by the participants. The implication of this is that it will likely affect the level of participation in the programme as farmer will only want to get involved in activity that they will benefit from either economical or socially.

Table 3: level of participant's satisfaction on WAAPP programme

\begin{tabular}{lcc}
\hline Level of satisfaction on WAAPP programmes & Mean & $\begin{array}{c}\text { Standard } \\
\text { deviation }\end{array}$ \\
\hline Method of information dissemination on the WAAPP & $\mathbf{2 . 2 2}$ & 0.702 \\
activities & 1.82 & 0.825 \\
The maize seed distribution method & 1.56 & 0.812 \\
The cassava stem distribution method & $\mathbf{2 . 1 0}$ & 0.755 \\
The channels used in execution of the scheme & $\mathbf{2 . 1 2}$ & 0.746 \\
The farmers sensitization processes on the programme & 1.52 & 0.735 \\
activities & 1.88 & 0.739 \\
The level of subsidy provided by the programme & 1.96 & 0.683 \\
Timely provision of the inputs & $\mathbf{2 . 1 5}$ & 0.780 \\
The ability to reconcile with the list of the farmers & 1.60 & 0.798 \\
The quality of maize seed provided & $\mathbf{2 . 0 8}$ & 0.560 \\
The quantity of maize seed/cassava & 1.69 & 0.735 \\
The general operations of the programme & 1.94 & 0.676 \\
Availability of water supply & $\mathbf{1 . 8 9}$ & \\
Availability of feed provided for the cat fish production & \\
Grand mean &
\end{tabular}

Source: Field Survey, 2017 
Creative Commons User License: CC BY-NC-ND

Abstracted by: EBSCOhost, Electronic Journals Service (EJS), Google Scholar, Journal Seek, Scientific Commons,

Food and Agricultural Organization (FAO), CABI and Scopus
Journal of Agricultural Extension

Vol. 23 (2) April, 2019

ISSN(e): 24086851; ISSN(Print); 1119944X

http://journal.aesonnigeria.org

http://www.ajol.info/index.php/jae

Email: editorinchief@aesonnigeria.org

\section{Constraints to Effective Utilization of WAAPP Programme}

Data in Table 4 show that the major constraints militating against effective implementation / utilization of WAAPP programme were: insufficient credit facilities $(\bar{x}=2.62)$, inadequate funding attached to each package of the project $(\bar{x}=2.59)$, high cost of production $(\bar{x}=2.58)$, unavailability of the fryers $(\bar{x}=2.47)$, poor storage facilities $(\bar{x}=2.45)$, inadequate water supply difficulty in getting water $(\bar{x}=2.44)$, lack of government commitment to policy issues $(\bar{x}=2.40)$, farmers' experience of difficulty in securing money for beneficiary contribution $(\bar{x}=2.24)$, high cost of transportation $(\bar{x}=2.14)$, inability of some farmers to still pay for the subsidized inputs like feed and water $(\bar{x}=2.13)$, lack of technical knowledge in the use of improve technologies $(\bar{x}=2.13)$, political instability in the country $(\bar{x}=2.09)$, poor marketing strategies $(\bar{x}=2.11)$ untimely counterpart funds from the donor $(\bar{x}=2.08)$ and untimely disbursement of inputs $(\bar{x}=2.02)$.

However, the following were not identified as major constraints militating against effective implementation of WAAPP programme: land tenure system $(\bar{x}=1.96)$, general reluctance on the part of the farmers to pay beneficiary contribution $(\bar{x}=1.94)$ lack of ready markets to sell the increased output as a result of securing productivity assets (cat fish) $(\bar{x}=1.86)$, dishonesty/corruption among officials $(\bar{x}=1.75)$, inability to read the pamphlet provided $(\bar{x}=1.60)$, farmers may not ask for non-agricultural based enterprise such as rental business $(\bar{x}=1.60)$, ineffective advisory services $(\bar{x}=1.57)$, inability of the farmers to access information on the WAAP activities $(\bar{x}=1.54)$ lack of mobility of staff $(\bar{x}=1.45)$,conflict between service providers in term of services to be rendered and client groups to serve $(\bar{x}=1.34)$, poor attitude of UNN staff towards farmers participating in the project $(\bar{x}=1.27)$.

The implication of this is that if the problem of insufficient credit facilities, inadequate funding attached to each package of the project, high cost of production, unavailability of the fryers, poor storage facilities, inadequate water supply, lack of government commitment to policy issues, high cost of transportation, inability of some farmers to still pay for the subsidized inputs, lack of technical knowledge in the use of improve technologies, Political instability in the country, poor marketing strategies, untimely counterpart funds from the donor and untimely disbursement of inputs could be solved, the programme will effectively meet and even surpass its objectives 
Creative Commons User License: CC BY-NC-ND

Abstracted by: EBSCOhost, Electronic Journals Service (EJS),

Google Scholar, Journal Seek, Scientific Commons,

Food and Agricultural Organization (FAO), CABI and Scopus
Journal of Agricultural Extension

Vol. 23 (2) April, 2019

ISSN(e): 24086851; ISSN(Print); 1119944X

http://journal.aesonnigeria.org

http://www.ajol.info/index.php/jae

Email: editorinchief@aesonnigeria.org

Table 4: Constraints to effective implementation/ utilization of WAAPP programme

\begin{tabular}{|c|c|c|}
\hline Constraints & Mean & Standard deviation \\
\hline Land tenure system problem & 1.96 & 0.916 \\
\hline Inadequate funding attached to each package of the project & 2.59 & 0.572 \\
\hline Untimely disbursement of inputs & 2.02 & 0.787 \\
\hline Untimely counterpart funds from the donor & 2.08 & 0.688 \\
\hline Poor attitude of UNN staff towards farmers participating in the project & 1.27 & 0.451 \\
\hline High cost of production & 2.58 & 0.538 \\
\hline Lack of government commitment to policy issues & 2.40 & 0.728 \\
\hline $\begin{array}{l}\text { Conflict between service providers in term of services to be rendered and client groups to } \\
\text { serve }\end{array}$ & 1.34 & 0.557 \\
\hline $\begin{array}{l}\text { Lack of ready markets to sell the increased output as a result of securing productivity } \\
\text { assets (cat fish) }\end{array}$ & 1.86 & 0.926 \\
\hline General reluctance on the part of the farmers to pay beneficiary contribution & 1.94 & 0.767 \\
\hline Farmers' experience of difficulty in security money for beneficiary contribution & 2.24 & 0.870 \\
\hline Insufficient credit availability & 2.62 & 0.602 \\
\hline Political instability in the country & 2.09 & 0.890 \\
\hline Dishonesty/corruption among officials & 1.75 & 0.758 \\
\hline Procurement of substandard income generating assets by contractors & 1.82 & 0.825 \\
\hline Farmers may not ask for non-agricultural based enterprise such as rental business & 1.60 & 0.808 \\
\hline Inability of the farmers to access information on the WAAP activities & 1.54 & 0.706 \\
\hline Inadequate water supply /Difficulty in getting water & 2.44 & 0.787 \\
\hline High cost of Transportation & 2.14 & 0.612 \\
\hline Unavailability of the fryers & 2.47 & 0.654 \\
\hline Inability of some farmers to still pay for the subsidized inputs like feed and water & 2.13 & 0.711 \\
\hline Inability to read the pamphlet provided & 1.60 & 0.742 \\
\hline Poor storage facilities & 2.45 & 0.686 \\
\hline Lack of technique knowledge in the use of improve technologies & 2.13 & 0.679 \\
\hline Poor marketing facilities & 2.11 & 0.729 \\
\hline Poverty level of the farmers & 2.40 & 0.771 \\
\hline Mortality/death of the( cat fish) & 2.17 & 0.702 \\
\hline Grand mean & 2.06 & \\
\hline
\end{tabular}

Source: Field survey, 2017

\section{Conclusion and Recommendations}

The respondents were satisfied with some operational process of the project and also had positive perception towards the implementation process of the project. The major constraint to the project was the inadequate funds attached to the package and the insufficient subsidy/financial constraints were factors that posed threat to effective implementation of the project

Going by the time-bound characteristics of agriculture, adequate funding, adequate and consistent procurement such as improved cassava stem cutting, improved maize seedling, fertilizer, fingerling, feed, at subsidized rate by the project will increase the beneficiaries' production and boost their confidence in the project and the government at large.

The project is highly appreciated in the study area, therefore government should increase the literacy level of the farmers through education as that farmer's access information and read agricultural pamphlet this will go a long way in making the project better.

More women should be sensitized and encouraged to participate in the project operation as the project does not discriminate against them 
Creative Commons User License: CC BY-NC-ND

Abstracted by: EBSCOhost, Electronic Journals Service (EJS), Google Scholar, Journal Seek, Scientific Commons,

Food and Agricultural Organization (FAO), CABI and Scopus
Journal of Agricultural Extension

Vol. 23 (2) April, 2019

ISSN(e): 24086851; ISSN(Print); 1119944X

http://journal.aesonnigeria.org

http://www.ajol.info/index.php/jae

Email: editorinchief@aesonnigeria.org

\section{References}

Anugwa, I.Q. Agwu, A.E. Anyanwu, I.A (2017). Catfish Farmers Perception of Training Effectiveness of the University of Nigeria-West Africa Agricultural Productivity Programme. Journal of Agricultural Extension 21(2)

Bernard, R. T \& Frankwell, W. D (2014). Access and use of mass media by small-scale farmers in accessing agricultural information for poverty alleviation in Tanzania: a case study of Kilombero district. First COTUL annual conference

Chambers Dictionary (2014). perception: Definition and Features $13^{\text {th }}$ edition, retrieved from www.chambers+dictionary+definition+of+perception

Emmanuel, A. B (2015). Cassava Farmers' Perceived Impact Of The West Africa Agricultural Productivity Programme On Their Livelihood Systems In Brong-Ahafo Region, Ghana. University of Cape Coast

Nwokocha, I. N , Anyaegbunam, H.N \& Igwe, C.O.K (2018)Assessment of farmers' perception and knowledge of improved food crops farming technologies in West African Agricultural Productivity Programme in Abia State, Nigeria. Journal of Community and Communication Research 3(1) Pp. 57-61

Otávio B. (2013). Perception and Conception: Shaping Human Minds. Springer Science Business Media Dordrecht 2013. 26 February pp 11-13.

Yolanda, E. A (2013). What is perception in psychology? Definition and Theory, retrieved from http://study.com/academy/lesson/what-is-perception-in-psychology-definition-theoryquiz.html on 20th march, 2017. 